\title{
Switching from twisted to planar oxalamide molecular clefts through intramolecular three centered hydrogen bonding
}

\author{
Itzia I. Padilla-Martínez, ${ }^{\text {** Francisco J. Martínez-Martínez, }}$

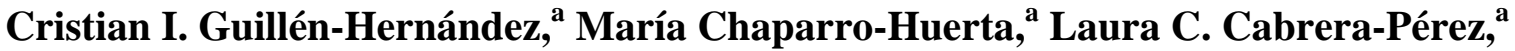 \\ Carlos Z. Gómez-Castro, ${ }^{a}$ Beatriz A. López-Romero, ${ }^{a}$ and Efrén V. García-Báeza \\ ${ }^{a}$ Departamento de Química, Unidad Profesional Interdisciplinaria de Biotecnología del Instituto \\ Politécnico Nacional, Av. Acueducto s/n, Barrio la Laguna Ticomán, México D.F. 07340. \\ México \\ ${ }^{b}$ Facultad de Ciencias Químicas, Universidad de Colima, km 9 Carretera Colima-Coquimatlán, \\ Colima 28400, México \\ E-mail: ipadilla@acei.upibi.ipn.mx
}

This paper is dedicated to Professor Eusebio Juaristi on the occasion of his $55^{\text {th }}$ anniversary (received 01 Jul 05; accepted 18 Aug 05; published on the web 23 Aug 05)

\begin{abstract}
The design, synthesis and structural characterization of thirteen bis-oxalamide molecular clefts are reported. ${ }^{1} \mathrm{H}$ NMR chemical shifts and $-\Delta \delta / \Delta \mathrm{T}$ coefficients of the $\mathrm{NH}$ protons were used to evaluate their mobilities and the role of hydrogen bonding interactions in stabilizing twisted or planar clefts in solution. Ab initio molecular orbital calculations at HF/6-31++G level of theory supported the experimental results. Finally the use of three-centered hydrogen bonding interactions to switch from twisted to planar molecular clefts was demonstrated.
\end{abstract}

Keywords: Oxalamide, oxamide, temperature dependence coefficient, three centered hydrogen bond, tweezer type clefts, planar clefts

\section{Introduction}

Investigations in the design and molecular synthesis of compounds having hydrogen bonding capabilities have had a great impact in the development of new drugs, because they can be used as artificial receptors for the study of molecular recognition processes, substrate-enzyme affinity or "host-guest" associations. ${ }^{1-3}$ In addition donor-acceptor interactions are involved in many biological events such as the tertiary structure of proteins and protein-drug complexes formation. ${ }^{4}$ Recent works show the great impact of hydrogen bonding interactions in the design and synthesis of artificial receptor molecules involving, for example, the synthesis of 
macrocycles containing amide groups, ${ }^{5,6}$ and tweezer-type molecules that form clefts and have been used as versatile artificial receptors for carboxylic acids, carbohydrates derivatives ${ }^{7}$ and anions. $^{8}$ Because guest molecules of biological interest may posses various numbers of protondonating and/or accepting groups, the design and synthesis of host clefts providing multiple hydrogen-bonding sites are desirable to maximize the recognition capacity and selectivity.

In this context, the synthesis and structural characterization by ${ }^{1} \mathrm{H}$ and ${ }^{13} \mathrm{C} \mathrm{NMR}$ spectroscopy of thirteen oxalamide clefts $\mathbf{2 a , b - 4 a , b}$ and $\mathbf{5 b - 1 1 b}$ derived from orto- (a series) and meta-phenylenediamine (b series), to be tested as artificial receptors, are reported. Oxalamide derivatives have been studied in the context of crystal engineering, ${ }^{9,10}$ their properties as gelators for organic solvents, ${ }^{11}$ as well as their capacity to form molecular complexes are known. ${ }^{12}$ Nevertheless, to our knowledge, its potential in the design of acceptor molecules has not been exploited, even when its use in molecular engineering has been theoretically envisaged. ${ }^{13}$ One of the main features of the oxalamide moiety is the very well known anti conformation between both carbonyls and the formation of three-centered hydrogen bonds. ${ }^{14}$ However, there are few examples of the use of the three-centered hydrogen bonding motif to control the secondary structures of artificial foldamers. ${ }^{15}$ The design is also based on the versatility provided by the phenylenediamine disubstitution of fixed opening angles of $60^{\circ}$ and $120^{\circ}$. In addition, the embrace capacity of the arms is assured with hydrogen bonding moieties bearing a pendant alkyl or aryl groups.

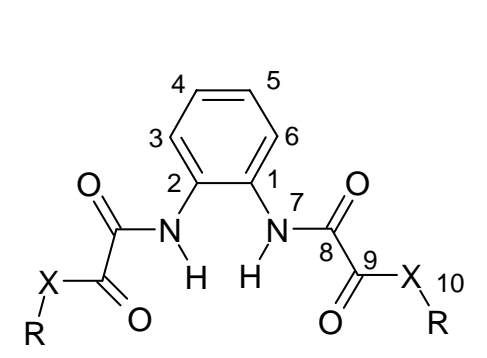

$1 a-4 a$

$$
\begin{aligned}
& \mathbf{1} X=\mathrm{O}, \mathrm{R}=\mathrm{Et} \\
& \mathbf{2} \mathrm{X}=\mathrm{NH}, \mathrm{R}=\mathrm{NH}_{2} \\
& \mathbf{3} \mathrm{X}=\mathrm{NH}, \mathrm{R}=\mathrm{CH}_{2} \mathrm{CH}_{2} \mathrm{OH} \\
& \mathbf{4} \mathrm{X}=\mathrm{NH}, \mathrm{R}=\mathrm{CH}_{2} \mathrm{CH}_{2} \mathrm{NHCH}_{2} \mathrm{CH}_{2} \mathrm{OH} \\
& \mathbf{5 X}=\mathrm{NH}, \mathrm{R}=(\mathrm{S}) \mathrm{CH}\left(\mathrm{CH}_{3}\right) \mathrm{CH}_{2} \mathrm{OH} \\
& \mathbf{6 X}=\mathrm{NH}, \mathrm{R}=(R) \mathrm{CH}\left(\mathrm{CH}_{3}\right)(\mathrm{S}) \mathrm{CH}\left(\mathrm{C}_{6} \mathrm{H}_{5}\right) \mathrm{OH}
\end{aligned}
$$

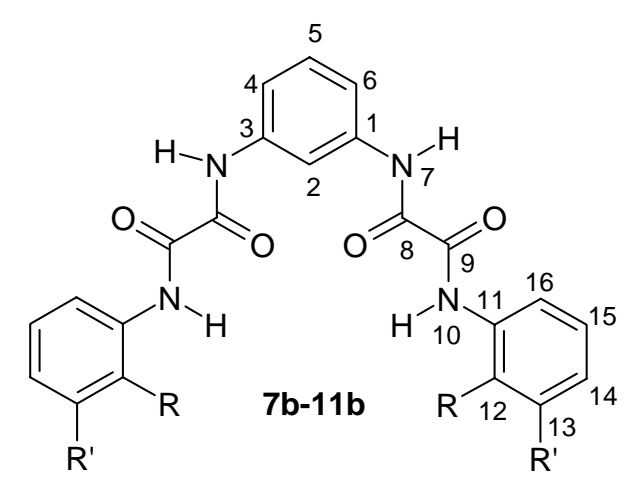

$$
\begin{array}{rl}
7 & R=H, R^{\prime}=O H \\
8 & R=O H, R^{\prime}=H \\
9 & R=F, R^{\prime}=H \\
10 & R=C O C H \\
3 & R^{\prime}=H \\
11 & R=N_{2}, R^{\prime}=H
\end{array}
$$

The aim of the work is to develop a new generation of functionalized molecular clefts whose recognition and assembling properties will be further studied. 


\section{Results and Discussion}

\section{Design}

The design of the artificial clefts, herein reported, was done taking into account three main structural requirements: hydrogen bonding capabilities, cleft size and flexibility. Continuing with our studies on the H-bonding behavior of the oxalyl group in oxalamates and oxalamides, ${ }^{14,16}$ the oxalyl group was selected as spacer and the main hydrogen bonding moiety. Therefore, an oxalamate 1a,b or oxalamide $\mathbf{2 a , b - 4 a , b}$ and $\mathbf{5 b - 1 1 b}$ cleft was formed attaching two pendant oxalyl groups to a disubstituted aniline. The cleft opening angle was fixed at $60^{\circ}$ and $120^{\circ}$ using 1,2- and 1,3-phenylenediamine, respectively. It is worthy to mention that the flexibility of the cleft was modulated using alkyl amines or substituted anilines, all of them provide additional hydrogen bonding sites to improve recognition process (Figure 1). Thus, the hidrazine 2a,b, ethanolamine $\mathbf{3 a , b}$ and $N$-(2-hydroxyethyl)ethylenediamine $\mathbf{4 a , b}$ flexible bis-oxalamide derivatives were synthesized, bearing an amino, hydroxy and amino-hydroxy groups, respectively, as additional HB recognition points. In this way, and with the aim of incorporating selectivity, the $(S)-(+)-2$-amino-1-propanol $\mathbf{5 b}$ and $(1 S, 2 R)-(+)$-norephedrine $\mathbf{6 b}$ derivatives were synthesized. The last group of compounds and the less flexible, are derived from ortho- and meta-substituted anilines $\mathbf{7 b - 1 1 b}$ bearing $\mathrm{H}$-bonding acceptor groups capable to form five $\mathbf{8 b}, \mathbf{9 b}$ or six 10b, 11b membered H-bonded rings of different strength.

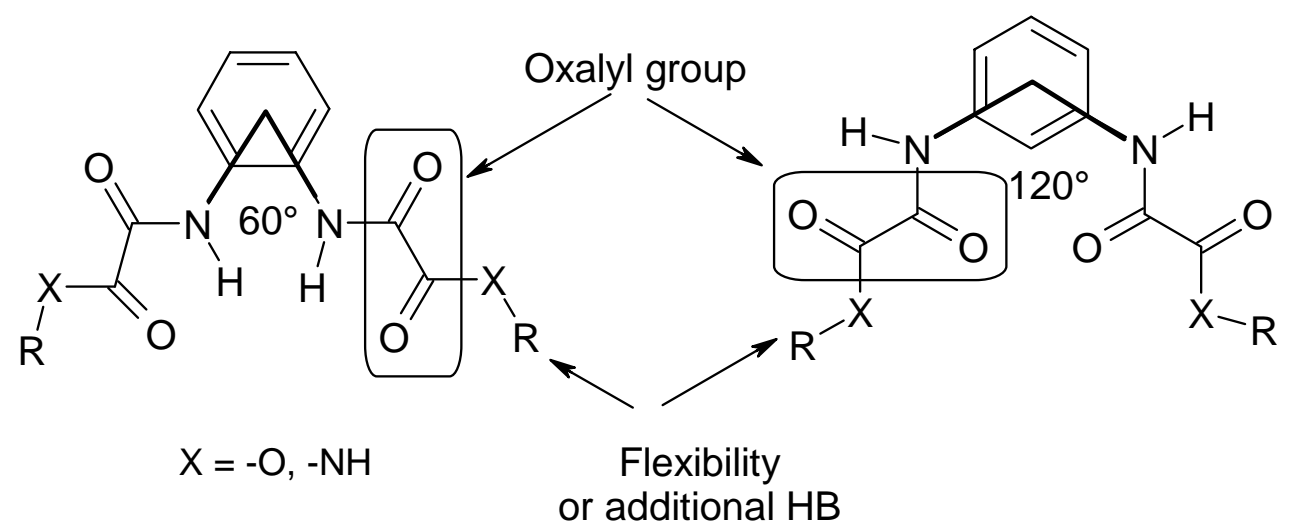

Figure 1. Structural elements considered in the design of oxalyl molecular clefts.

This rational design allowed us the synthesis of the molecular oxalamide clefts: $N, N$ '-1,2bis[(2-hydrazino)oxalyl]phenylenediamine 2a, $N, N^{\prime}$-1,3-bis[(2-hydrazino)oxalyl]phenylenediamine 2b, $N, N^{\prime}$-1,2-bis[2-(2-hydroxy-ethylamino)oxalyl]phenylenediamine 3a, $N, N$ '-1,3-bis[2-(2-hydroxy-

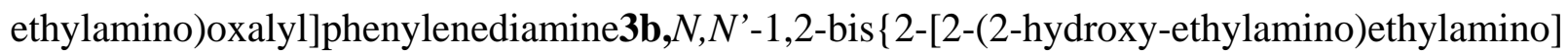
oxalyl \}phenylenediamine4a, $N, N^{\prime}$-1,3-bis $\{2$-[2-(2-hydroxy-ethylamino)ethylamino]oxalyl phenylenediamine4b, $N, N$ '-1,3-bis[2-(2-hydroxy-1(S)-methyl-ethylamino)oxalyl]Phenylene diamine5b, $N, N^{\prime}$-1,3-bis[2-(2(S)-hydroxy-1(R)-methyl-2-phenyl-ethylamino)oxalyl]phenylene 
diamine 6b, $N, N^{\prime}$-1,3-bis[2-(3-hydroxy-phenylamino)oxalyl]phenylenediamine $7 \mathbf{b}, \quad N, N^{\prime}-1,3-$ bis[2-(2-hydroxy-phenylamino)oxalyl]phenylenediamine8b, $N, N$ '-1,3-bis[2-(3-fluoro-phenyl amino)oxalyl]phenylenediamine9b, $N, N$ '-1,3-bis[2-(2-acetyl-phenylamino)oxalyl]phenylene diamine 10b, $N, N^{\prime}$-1,3-bis[2-(2-nitro-phenylamino)oxalyl]phenylenediamine $11 \mathbf{b}$.

\section{Synthesis}

The first step in the synthesis of this oxalyl clefts is the condensation reaction of orto- and metaphenylenediamine with ethyl oxalyl chloride to give the oxalamate clefts 1a,b (Scheme 1). These intermediate products were used as synthons for the synthesis of oxalamides $\mathbf{2 a , b - 4 a , b}$ and $\mathbf{5 b}$ 6b by a subsequent condensation reaction with the corresponding alkylamines. Whereas oxalamides $7 \mathbf{b}-\mathbf{1 1 b}$ were obtained in one pot reaction after the addition in situ of the corresponding aniline to the intermediate $\mathbf{A}$, which was previously formed by condensation of 1,3-phenylenediamine with two equivalents of oxalyl chloride (Scheme 2). All compounds were analyzed in solution by ${ }^{1} \mathrm{H}$ and ${ }^{13} \mathrm{C}$ NMR spectroscopy. It is worthy to mention that following the same procedure for 1,2-phenylenediamine or starting from the oxalamate 1a, we were unable to synthesize 7a-11a and instead, only 2,3-quinazolinedione was obtained.

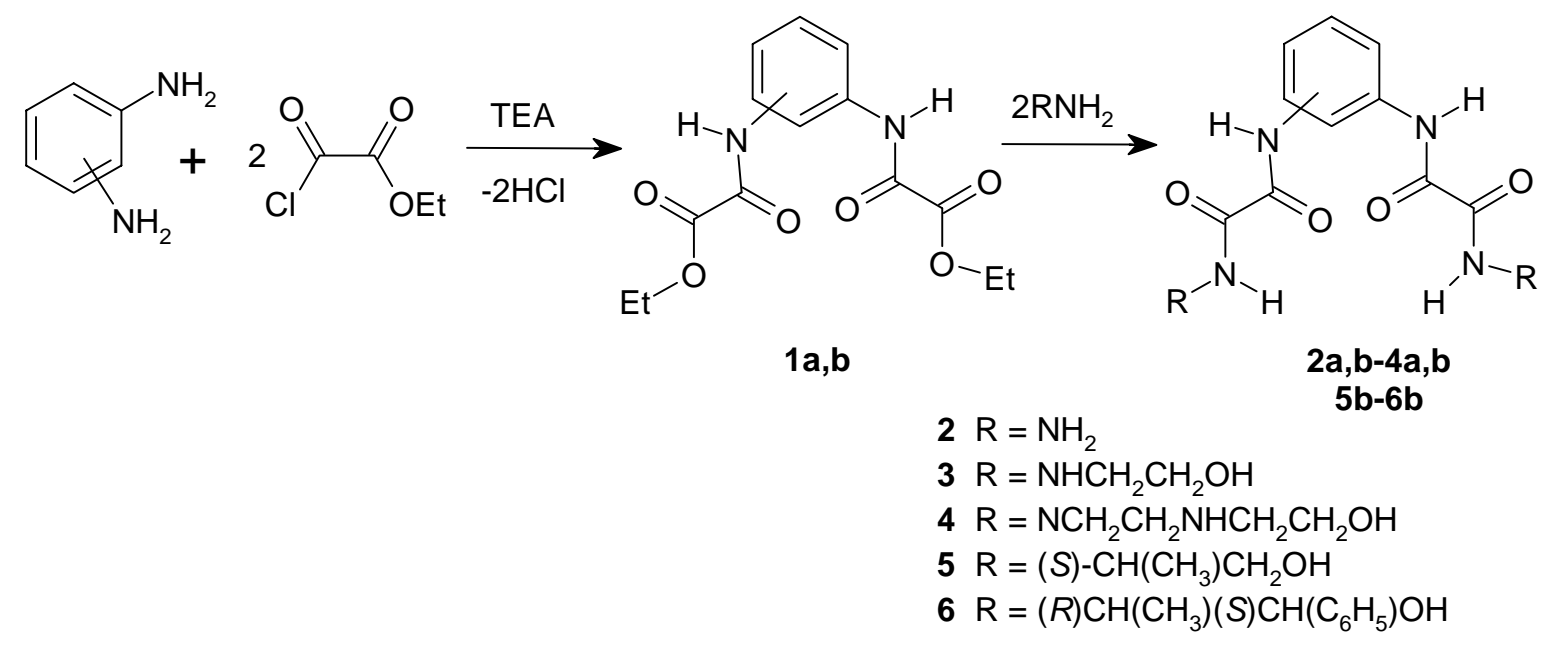

\section{Scheme 1}


<smiles>Nc1cccc(N)c1</smiles><smiles>[R]c1ccc(N)c(N)c1CC(=O)Nc1cc(NC(=O)C(=O)Cl)cc(N([Tl])C(=O)C(=O)Cl)c1</smiles>

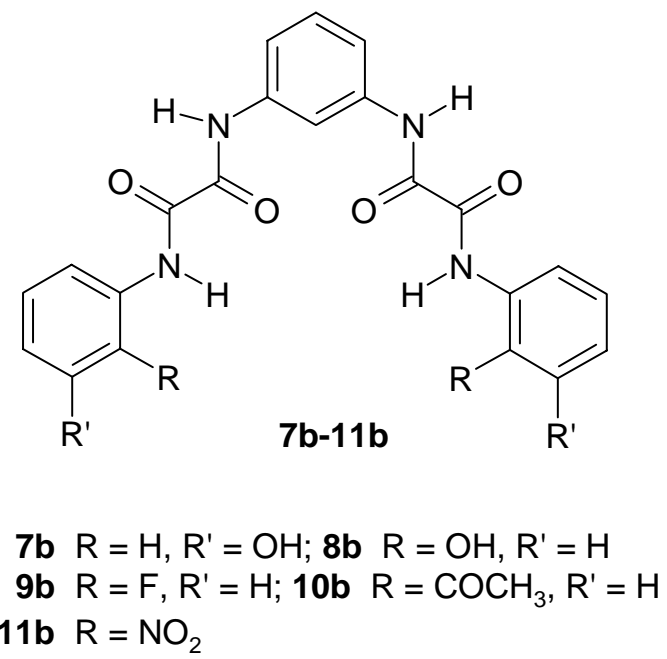

\section{Scheme 2}

\section{${ }^{1}$ H NMR analysis}

The ${ }^{1} \mathrm{H}$ NMR chemical shifts of compounds 1a,b-4a,b and 5b-11b in $\left[{ }^{2} \mathrm{H}_{6}\right]$-DMSO, are listed in Table 1 . The ${ }^{1} \mathrm{H}$ NMR analysis of compounds $\mathbf{1 a - 4 a}$, which are characterized by an opening angle of $60^{\circ}$, show an AA'BB' system between 7.23-7.62 ppm. Whereas compounds 1b-11b, with an opening of angle of $120^{\circ}$, show three types of aromatic signals: a singlet shifted to high frequencies lying between 8.17 and $8.56 \mathrm{ppm}$, which was assigned to H2 proton; a doublet between 7.46 and 7.59 ppm corresponding to $\mathrm{H} 4$ and $\mathrm{H} 6$ protons; and finally, at lower frequencies, a triplet signal for $\mathrm{H} 5$ proton between 7.28 and $7.36 \mathrm{ppm}$ was observed.

The pendant arms of molecules 3a,b and 4a,b display a double of triplet signal between 3.24 and $3.34 \mathrm{ppm}$ for the methylene protons by coupling with the $\mathrm{N} 10 \mathrm{H}$ proton, and between 3.4 and $3.5 \mathrm{ppm}$ a triple signal for the methylene protons near to the $\mathrm{OH}$ group. In addition at 2.6-2.7 ppm appear the signals for the methylene groups near to the amino group in compounds 4a,b. The methyne and methylene protons are displayed at 4.27 and $3.88 \mathrm{ppm}$, for $\mathbf{5 b}$, respectively, and methyne groups are at 4.00 and $4.69 \mathrm{ppm}$ for compound $\mathbf{6 b}$. Compounds $\mathbf{7 b}$ 11b, which bear pendant aromatic groups, display the characteristic coupling pattern according to 1,2- and 1,3-substitution.

The amide N7H proton of compounds 1a-4a display a simple signal between 10.30 to 10.47 ppm, more shifted to lower frequencies than in the analogous compounds $\mathbf{1 b}-\mathbf{4} \mathbf{b}$, whose $\mathrm{N7H}$ proton appear between 10.58-10.85 ppm. In the b series this signal was assigned by NOE effect with H2, whereas in the a series it was assigned by comparison with some oxalamide derivatives previously described. ${ }^{14}$ These differences point out that $\mathrm{N} 7 \mathrm{H}$ proton is more engaged in H-bonding interactions with amide carbonyl $\mathrm{C} 9=\mathrm{O}$, in the $\mathbf{b}$ than in the a series. The $\mathrm{H} 2$ chemical shift is particularly informative in this regard. As mentioned before, it is shifted to high

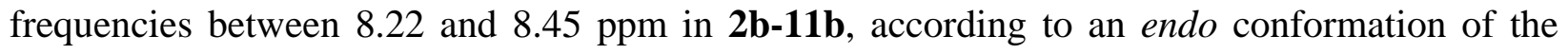
carbonyl amide $\mathrm{C} 8=\mathrm{O}$ group. Thus a three centered hydrogen bonding interaction 
$\mathrm{C} 8=\mathrm{O} \cdots \mathrm{H} 2 \cdots \mathrm{O}=\mathrm{C} 8$ is formed, which exerts a cooperative effect with the simpler one $\mathrm{N} 7 \mathrm{H} \cdots \mathrm{O}=\mathrm{C} 9$ to give, on these molecules, a planar conformation observable in the ${ }^{1} \mathrm{H}$ NMR time scale. This result is in agreement with those found measuring combustion enthalpies. ${ }^{17}$ In the a series, the close proximity of both arms as well as the absence of the three centered hydrogen bonding interaction allow a twisted conformation with both arms out of the plane of the aromatic ring but forming the aforementioned $\mathrm{N} 7 \mathrm{H} \cdots \mathrm{O}=\mathrm{C} 9 \mathrm{H}$-bonding interaction.

Table 1. ${ }^{1} \mathrm{H}$ NMR chemical shifts of compounds $\mathbf{1 a , b}-\mathbf{4 a}$,b and $\mathbf{5 b - 1 1 b}$ in $\left[{ }^{2} \mathrm{H}_{6}\right] \mathrm{DMSO}$

\begin{tabular}{|c|c|c|c|c|c|c|c|c|}
\hline Compound & $\mathrm{H} 2$ & H3 & $\mathrm{H} 4$ & H5 & H6 & N7-H & N10-H & $\mathrm{OH}$ \\
\hline $1 \mathrm{a}^{\mathrm{a}}$ & --- & \multicolumn{4}{|c|}{$7.27-7.59$} & 10.40 & & \\
\hline $1 b^{b}$ & 8.17 & --- & 7.46 & 7.30 & 7.46 & 10.82 & & \\
\hline $2 a^{c}$ & --- & \multicolumn{4}{|c|}{$7.24-7.59$} & 10.44 & 10.34 & \\
\hline $2 b^{d}$ & 8.36 & --- & 7.48 & 7.28 & 7.48 & 10.57 & 10.27 & \\
\hline $3 a^{e}$ & --- & \multicolumn{4}{|c|}{$7.24-7.61$} & 10.47 & 8.86 & 4.79 \\
\hline $3 b^{f}$ & 8.38 & --- & 7.57 & 7.37 & 7.57 & 10.70 & 8.88 & 4.86 \\
\hline $4 a^{g}$ & --- & \multicolumn{4}{|c|}{$7.23-7.62$} & 10.30 & 8.89 & 4.45 \\
\hline $4 b^{h}$ & 8.29 & --- & 7.48 & 7.28 & 7.48 & 10.60 & 8.86 & 4.55 \\
\hline $5 b^{i}$ & 8.22 & --- & 7.48 & 7.29 & 7.48 & 10.58 & 8.52 & 4.84 \\
\hline $6 b^{j}$ & 8.25 & --- & 7.47 & 7.34 & 7.47 & 10.57 & 8.58 & 5.60 \\
\hline $7 b^{k}$ & 8.42 & --- & 7.56 & 7.35 & 7.56 & 10.85 & 9.52 & 10.07 \\
\hline $8 b^{l}$ & 8.45 & --- & 7.54 & 7.36 & 7.54 & 10.78 & 9.85 & 10.48 \\
\hline $9 b^{m}$ & 8.45 & --- & 7.56 & 7.36 & 7.56 & 10.83 & 10.47 & \\
\hline $10 b^{n}$ & 8.56 & --- & 7.59 & 7.36 & 7.59 & 10.93 & 12.93 & \\
\hline $11 b^{\circ}$ & 8.57 & --- & 7.59 & 7.37 & 7.59 & 11.08 & 11.70 & \\
\hline
\end{tabular}

${ }^{\mathrm{a}} \mathrm{OCH}_{2}$ 4.29, $\mathrm{CH}_{3}$ 1.30; ${ }^{\mathrm{b}} \mathrm{OCH}_{2}$ 4.27, $\mathrm{CH}_{3}$ 1.27; ${ }^{\mathrm{c}} \mathrm{NH}_{2} 4.2$ and 4.8; ${ }^{\mathrm{d}} \mathrm{NH}_{2}$ 4.6; ${ }^{\mathrm{e}} \mathrm{OCH}_{2} 3.48, \mathrm{NCH}_{2}$ 3.26; ${ }^{\mathrm{f}} \mathrm{OCH}_{2}$ 3.55, $\mathrm{NCH}_{2}$ 3.34; ${ }^{\mathrm{g}} \mathrm{OCH}_{2}$ 3.41, $\mathrm{NH} 3.32, \mathrm{~N} 10 C H_{2} 3.25, \mathrm{NHCH}_{2}$ 2.64, $\mathrm{N} \mathrm{CCH}_{2} \mathrm{CH}_{2}$ 2.55; ${ }^{\mathrm{h}} \mathrm{OCH}_{2}$ 3.38, NH not observed, $\mathrm{N} 10 \mathrm{CH}_{2} 3.24, \mathrm{NHCH}_{2} 2.68, \mathrm{~N}^{2} \mathrm{CH}_{2} \mathrm{CH}_{2}$ 2.59; ${ }^{\mathrm{i}} \mathrm{N} 10 \mathrm{CH}$ 4.27, $\mathrm{OCH}_{2}$ 3.88, $\mathrm{CH}_{3}$ 1.08; ${ }^{\mathrm{j}} \mathrm{N} 10 \mathrm{CH}$ 4.00, OCH 4.69, Ph 7.20-7.34; ${ }^{\mathrm{k}} \mathrm{H} 12$ 7.38, H14,16 6.55, H15 7.24; ' H13 6.96, H14 6.86, H15 7.01, H16 8.14; ${ }^{\mathrm{m}} \mathrm{H} 13$ 8.16, H14 7.33, H15 7.72, H16 8.67; ${ }^{\mathrm{n}} \mathrm{H} 13$ 8.66, H14 7.34, H15 7.71, H16 8.15, $\mathrm{CH}_{3}$ 2.69; ${ }^{\circ} \mathrm{H} 13$ 8.17, H14 7.44, H15 7.8, H16 8.29.

The conformation in the open end of the molecule exert a strong effect on the chemical shift of the amide $\mathrm{N} 10 \mathrm{H}$ proton. In the ethanoloxalamide derivatives the $\mathrm{N} 10 \mathrm{H}$ signal lies between 8.52 and $8.89 \mathrm{ppm}$, appearing as a triplet by coupling with the methylene protons in $\mathbf{3 a}, \mathbf{b}-\mathbf{4 a}, \mathbf{b}$, and as a doublet by coupling with the methyne proton in $\mathbf{5 b}$ and $\mathbf{6 b}$. The $\mathrm{N} 10 \mathrm{H}$ chemical shift of this set of compounds is out of the range expected for strong H-bonding interactions, pointing out that the arms are flexible even twisted from the plane of the closed end of the cleft, in solution. 
In contrast, hydrazine $\mathbf{2 a , b}$ and aniline $\mathbf{7 b - 1 1 b}$ derivatives, display a chemical shift for $\mathrm{N} 10 \mathrm{H}$ strongly influenced by the formation of H-bonding interactions. The comparison between the $\mathrm{N} 10 \mathrm{H}$ chemical shifts of the $m$-hydroxy and $o$-hydroxy aniline derivatives $\mathbf{7} \mathbf{b}$ and $\mathbf{8 b}$, whose chemical shifts are 9.52 and 9.85 ppm, respectively, allowed us to propose the formation of the intramolecular three centered H-bonding interaction $\mathrm{C} 8=\mathrm{O} \cdots \mathrm{H} 10 \cdots \mathrm{O} 12$ in $\mathbf{8 b}$ that displace the $\mathrm{N} 10 \mathrm{H}$ chemical shift to higher frequencies in relation to the simpler $\mathrm{H}$-bonding system in $\mathbf{7 b}$. The formation of three centered H-bond is more evident in compounds $\mathbf{9 b - 1 1 b}$ which bear good hydrogen bonding acceptors to form $\mathrm{C} 8=\mathrm{O} \cdots \mathrm{H} \cdots \mathrm{F}, \mathrm{C} 8=\mathrm{O} \cdots \mathrm{H} \cdots \mathrm{O}=\mathrm{C}$ and $\mathrm{C} 8=\mathrm{O} \cdots \mathrm{H} \cdots \mathrm{ONO}$ interactions, respectively. Thus, the combined effect of this last three centered $\mathrm{H}$-bonding interaction, the above mentioned $\mathrm{C} 8=\mathrm{O} \cdots \mathrm{H} 2 \cdots \mathrm{O}=\mathrm{C} 8$ and $\mathrm{N} 7 \mathrm{H} \cdots \mathrm{O}=\mathrm{C}$, three centered and simple H-bonding interactions, respectively, confer a full planar arrangement to compounds $\mathbf{8 b - 1 1 b}$, whose conformation allow the formation of planar clefts, stable enough to remain as the principal conformer in solution.

Further evidence of the role played by the three centered intramolecular H-bonding interaction in the stabilization of the solution conformation of the bis-oxalamides $\mathbf{3 a}, \mathbf{b}-\mathbf{4 a}, \mathbf{a}$ and $5 \mathbf{b}-\mathbf{1 1 b}$, was given by the temperature dependence coefficients $\left(\Delta \delta / \Delta \mathrm{T}\right.$ in $\left.\mathrm{ppb} \mathrm{K}^{-1}\right)$ of the $\mathrm{NH}$ chemical shifts resonances in $\left[{ }^{2} \mathrm{H}_{6}\right]$ DMSO, which are listed in Table 2.

Table 2. Temperature dependence coefficients of $\mathrm{N7H}, \mathrm{N} 10 \mathrm{H}$ and $\mathrm{OH}$ chemical shifts of compounds 3a,b-4a,b and $\mathbf{5 b - 1 1 b}$ in $\left[{ }^{2} \mathrm{H}_{6}\right] \mathrm{DMSO}^{\mathrm{a}}$

\begin{tabular}{cccc}
\hline \multicolumn{4}{c}{$-\Delta \delta / \Delta \mathrm{T} / \mathrm{ppb} \mathrm{K}^{-1}$} \\
\hline Compound & $\mathrm{N} 7-\mathrm{H}$ & $\mathrm{N} 10-\mathrm{H}$ & $\mathrm{OH}$ \\
\hline 3a & $4.6( \pm 0.1)$ & $4.00( \pm 0.04)$ & $3.70( \pm 0.04)$ \\
3b & $4.62( \pm 0.02)$ & $4.29( \pm 0.07)$ & $4.05( \pm 0.11)$ \\
4a & broad & $4.67( \pm 0.06)$ & \\
4b & $4.57( \pm 0.01)$ & $3.97( \pm 0.07)$ & \\
5b & $4.60( \pm 0.03)$ & $4.2( \pm 0.1)$ & $3.59( \pm 0.03)$ \\
6b & $4.30( \pm 0.1)$ & $4.1( \pm 0.1)$ & $3.32( \pm 0.04)$ \\
7b & $4.64( \pm 0.01)$ & $4.47( \pm 0.07)$ & $4.69( \pm 0.02)$ \\
8b & $4.94( \pm 0.02)$ & $0.75( \pm 0.01)$ & $5.92( \pm 0.07)$ \\
9b & $4.43( \pm 0.02)$ & $4.64( \pm 0.09)$ & \\
10b & $4.88( \pm 0.02)$ & $3.13( \pm 0.02)$ & \\
11b & $4.52( \pm 0.04)$ & $2.14( \pm 0.01)$ & \\
\hline
\end{tabular}

${ }^{\mathrm{a} C}$ Correlation coefficients at least of 0.999 .

It is known that the $\Delta \delta / \Delta \mathrm{T}$ values are directly related to the proton mobility, ${ }^{18}$ thus the $\mathrm{N} 7 \mathrm{H}$ proton is much more mobile than $\mathrm{N} 10 \mathrm{H}$, in both series, with a mean value around $4.6( \pm 0.3) \mathrm{ppb}$ $\mathrm{K}^{-1}$. In the other hand, derivatives $\mathbf{8 b - 1 1 b}$ clearly show the strong dependence of $\mathrm{N} 10 \mathrm{H} \Delta \delta / \Delta \mathrm{T}$ values with the nature of the 2-substituted aniline, following the order: $\mathrm{F}>\mathrm{COCH}_{3}>\mathrm{NO}_{2}>\mathrm{OH}$. 
The role played by the three centered H-bonding interaction in the mobility of $\mathrm{N} 10 \mathrm{H}$ is highlighted by comparison of the $\Delta \delta / \Delta \mathrm{T}$ value of compounds $\mathbf{7 b}$ ( $\mathrm{m}$-substituted) and $\mathbf{8 b}(\mathrm{b}-$ substituted), the former being unable to form this interaction, with values of $4.7( \pm 0.7)$ and 0.75 $( \pm 0.01) \mathrm{ppb} \mathrm{K}^{-1}$, respectively. Finally, the $\mathrm{OH} \Delta \delta / \Delta \mathrm{T}$ values are in agreement with its alcoholic or phenolic nature.

\section{${ }^{13} \mathrm{C}$ NMR analysis}

The ${ }^{13} \mathrm{C}$ NMR spectra of the bis-oxalamates $\mathbf{1 a}, \mathbf{b}$ and bis-oxalamides $\mathbf{2 a , b}-\mathbf{4 a}, \mathbf{b}$ and $\mathbf{5 b} \mathbf{b}-\mathbf{1 1} \mathbf{b}$, show half of the total carbon atom signals, indicating symmetry. The central aromatic ring of compound 1a-4a showed three signals between 125.4-129.8 ppm whereas compounds 1b-11b show four signals between 113.5 to 138.5 ppm, in accordance with the expected 1,2- and 1,3disubstitution pattern. Previously, it has been demonstrated by X-ray studies that the oxalyl moiety can be considered as two independent carbonyls, bonded together by a single $\mathrm{C}\left(s p^{3}\right)-\mathrm{C}\left(s p^{3}\right)$ bond. $^{19}$ Thus oxalamates 1a,b are composed by an amide and an esther groups, ${ }^{20}$ and oxalamides $\mathbf{2 a , b}-\mathbf{4 a}, \mathbf{b}$ and $\mathbf{5 b - 1 1} \mathbf{b}$ by two independent amides. However, amide carbonyl chemical shift of oxalamate derivatives 1a,b was more shifted to low frequencies (155.5$156.4 \mathrm{ppm}$ ) than in oxalamides (157.2-159.5), suggesting that, in the former group, the electronic density of nitrogen is more engaged with carbonyl than in the last. These results are in agreement with those reported elsewhere. ${ }^{16}$

Table 3. ${ }^{13} \mathrm{C}$ NMR chemical shifts of compounds $\mathbf{1 a}, \mathbf{b}-\mathbf{4 a}, \mathbf{b}$ and $\mathbf{5 b - 1 1 b}$ in $\left[{ }^{2} \mathrm{H}_{6}\right] \mathrm{DMSO}$

\begin{tabular}{|c|c|c|c|c|c|c|c|}
\hline Compound & C1 & $\mathrm{C} 2$ & C3 & $C 4^{\mathrm{a}}$ & $\mathrm{C}^{\mathrm{b}}$ & C8 & C9 \\
\hline $1 a^{c}$ & \multicolumn{2}{|c|}{129.6} & 126.4 & \multicolumn{2}{|c|}{125.7} & 155.5 & 160.3 \\
\hline $1 b^{d}$ & 138.3 & 113.5 & 138.3 & 117.7 & 129.6 & 156.4 & 161.3 \\
\hline $2 \mathrm{a}$ & \multicolumn{2}{|c|}{129.8} & 126.1 & \multicolumn{2}{|c|}{125.4} & 157.3 & 158.3 \\
\hline $2 b$ & 138.5 & 113.6 & 138.5 & 117.5 & 129.4 & 158.6 & 159.0 \\
\hline $3 \mathrm{a}^{\mathrm{e}}$ & \multicolumn{2}{|c|}{129.8} & 126.1 & \multicolumn{2}{|c|}{125.4} & 158.7 & 159.6 \\
\hline $3 b^{f}$ & 138.4 & 113.7 & 138.4 & 117.7 & 129.4 & 159.2 & 160.6 \\
\hline $4 a^{g}$ & \multicolumn{2}{|c|}{129.8} & 126.1 & \multicolumn{2}{|c|}{125.4} & 158.7 & 159.5 \\
\hline $4 b^{h}$ & 138.4 & 113.7 & 138.4 & 117.7 & 129.4 & 159.2 & 160.7 \\
\hline $5 b^{i}$ & 137.9 & 113.3 & 137.9 & 117.2 & 129.0 & 158.0 & 159.6 \\
\hline $6 b^{j}$ & 138.4 & 113.7 & 138.4 & 117.7 & 129.5 & 159.1 & 159.5 \\
\hline $7 b^{j}$ & 139.2 & 114.0 & 139.2 & 117.9 & 129.5 & 159.2 & 159.5 \\
\hline $8 b^{k}$ & 138.5 & 114.3 & 138.5 & 118.0 & 129.5 & 158.0 & 159.2 \\
\hline $9 b^{l}$ & 138.0 & 114.2 & 138.0 & 118.2 & 129.6 & 158.9 & 159.4 \\
\hline $10 b^{\mathrm{m}}$ & 138.4 & 114.2 & 138.4 & 118.2 & 129.5 & 158.9 & 159.4 \\
\hline $11 b^{n}$ & 136.4 & 114.2 & 136.4 & 118.3 & 129.6 & 158.4 & 159.1 \\
\hline
\end{tabular}

${ }^{\mathrm{a}} \delta \mathrm{C} 3=\delta \mathrm{C} 6$ in a series; ${ }^{\mathrm{b}} \delta \mathrm{C} 4=\delta \mathrm{C} 6$ in b series; ${ }^{\mathrm{c}} \mathrm{OCH}_{2} 62.6, \mathrm{CH}_{3} 13.8 ;{ }^{\mathrm{d}} \mathrm{OCH}_{2} 63.0, \mathrm{CH}_{3} 14.5$; ${ }^{\mathrm{e}} \mathrm{OCH}_{2}$ 59.0, $\mathrm{NCH}_{2}$ 42.0; ${ }^{\mathrm{f}} \mathrm{OCH}_{2}$ 59.8, $\mathrm{NCH}_{2}$ 42.5; ${ }^{\mathrm{g}} \mathrm{OCH}_{2}$ 60.4, $\mathrm{OCH}_{2} \mathrm{CH}_{2}$ 51.3, $\mathrm{N} 10 \mathrm{CH}_{2} \mathrm{CH}_{2}$ 


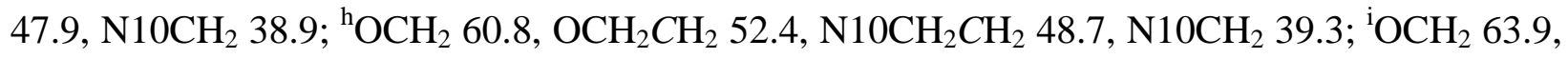
$\mathrm{NCH}$ 47.6, $\mathrm{CH}_{3}$ 16.6; ${ }^{\mathrm{j}} \mathrm{OCH}$ 74.5, $\mathrm{NCH}$ 51.8, $\mathrm{CH}_{3}$ 15.5, Ph: 143.6(i), 128.5(o), 126.9(m), 127.6(p); $\delta \mathrm{C} 11-\mathrm{C} 16:{ }^{\mathrm{j}} 138.5,108.6,158.4,112.7,130.0,112.1 ;{ }^{\mathrm{k}} 125.8,148.0,116.0,127.0$, 120.0, 125.9; ${ }^{\mathrm{l}} 120.8,158.2$, 116.6, 125.2, 125.8, 127.8; ${ }^{\mathrm{m}} 138.6,135.2,133.0,133.0,124.8$, 124.9, $\mathrm{CH}_{3} 29.3 ;{ }^{\mathrm{n}} 138.3,140.5,124.2,126.4,135.9,132.2$.

\section{Ab initio molecular orbital calculations}

In order to gain more insight about the preferred conformation of the molecular clefts analyzed herein, and the role played by the hydrogen bonding interactions, $a b$ initio molecular orbital calculations at HF/6-31++G level of theory were performed for three different conformers of compounds 1a and 1b, these molecules were chosen as models because of their relative small size and also because their X-ray structure is known. Each conformer was geometry optimized to a local minimum and, in the case of $\mathbf{1 b}$, a single point calculation was performed to obtain the atomic charges according to the Merz-Kollman-Singh scheme. Due to the close nearby of both arms, the X-ray structure of $\mathbf{1 a}^{21}$ shows the twisted conformation endo(anti)-exo(syn) [Fig. (2a)], which is less stable by $1.8 \mathrm{kcal} \mathrm{mol}^{-1}$ than the most stable one predicted by calculations the endo(anti)-exo(anti) [Fig. (2b)]. This last conformer is practically isoenergetic to the exo(anti)exo(anti) conformer [Fig. (2c)], also calculated. This result is in agreement with the anti conformation between both oxalyl carbonyls frequently found for other oxalamides. ${ }^{10,14,16,20,22}$

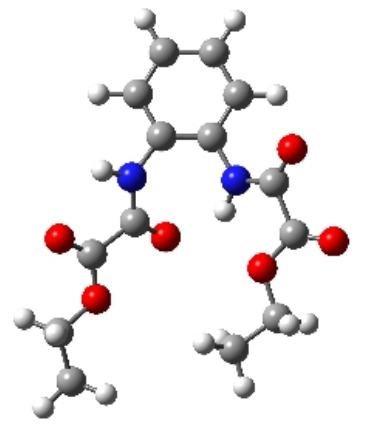

(a)

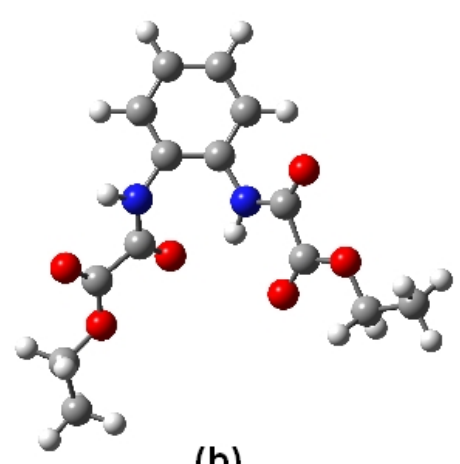

(b)

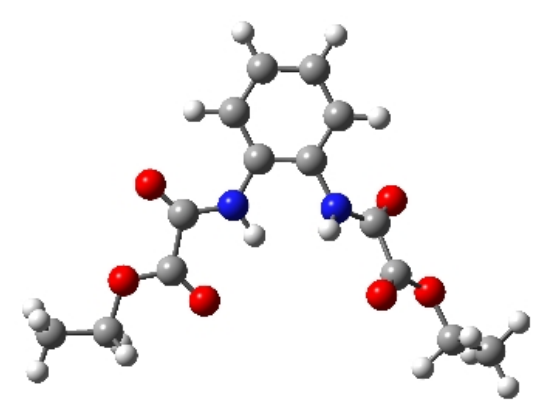

(c)

Figure 2. Molecular structure of the three tested conformers of 1a at HF/6-31++G level: (a) endo(anti)-exo(syn) (found by X-ray), (b) endo(anti)-exo(anti), the most stable and (c) exo(anti)exo(anti).

The X-ray structure of $\mathbf{1 b}$ is also known, ${ }^{22}$ showing an endo(anti)-endo(anti) [Fig. (3a)] conformation whereas the most stable conformer, according to calculations, is the endo(anti)exo(anti) [Fig. (3b)] by $2.0 \mathrm{kcal} \mathrm{mol}^{-1}$, the exo(anti)-exo(anti) conformer [Fig. (3c)] is almost of the same energy than this last one (less than $1 \mathrm{kcal} \mathrm{mol}^{-1}$ ) (Figure 3). Thus, the intramolecular hydrogen bonding should play an important role in stabilizing the conformations of higher energy for both compounds 1a and 1b. By X-ray diffraction, an intramolecular three centered 
hydrogen bond between both arms involving an oxalamide proton is clearly demonstrated for 1a, but in the case of $\mathbf{1 b}$, the crystal data strongly points to the existence of a three centered $\mathrm{H}$ bonding interaction involving the $\mathrm{C} 2-\mathrm{H}$ hydrogen atom, as donor. Further support to this last proposal is given by the analysis of the formal charges of $\mathbf{1 b}$, the $\mathrm{C} 2-\mathrm{H}$ hydrogen atom bears a positive charge of 0.389 , even higher than the charge of 0.365 of an oxalamide $\mathrm{NH}$ hydrogen in the endo(anti)-endo(anti) conformation, in contrast with the charges of 0.358 and 0.280 in the endo(anti)-exo(anti) and exo(anti)-exo(anti) conformers, respectively.

These results are in agreement with the above mentioned proposal of a twisted conformation for the a series and the contribution of the three centered H-bonding interaction $\mathrm{C} 8=\mathrm{O} \cdots \mathrm{H} 2 \cdots \mathrm{O}=\mathrm{C} 8$ and the simple $\mathrm{N} 7 \mathrm{H} \cdots \mathrm{O}=\mathrm{C} 9$ interaction to the observed endo(anti)-endo(anti) conformation of the $\mathbf{b}$ series.

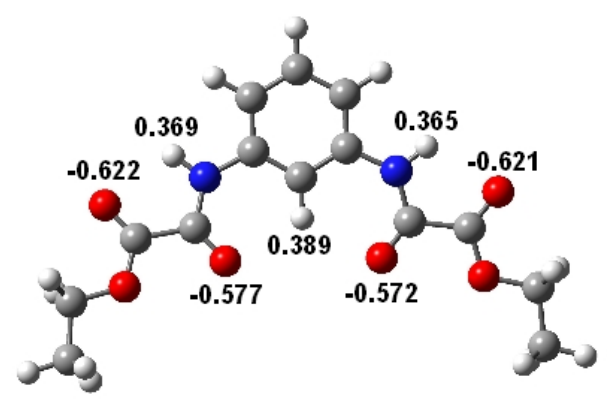

(a)

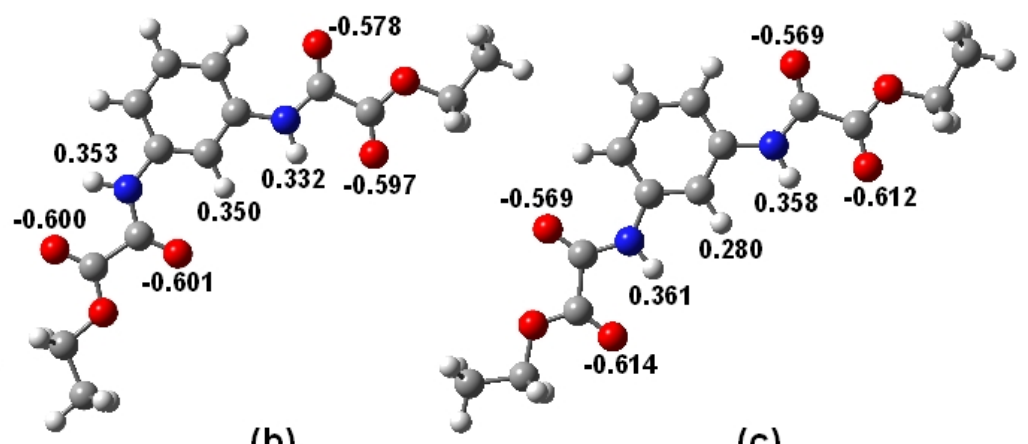

(b) (c)

Figure 3. Molecular structure and charges of the three tested conformers of $\mathbf{1 b}$ at HF/6-31++G level: (a) endo(anti)-endo(anti) (found by X-ray), (b) endo(anti)-exo(anti), the most stable and (c) exo(anti)-exo(anti).

\section{Conclusions}

In summary, a general efficient approach for the construction of twisted or planar molecular clefts derived from oxalamides is reported. The role of intramolecular three-centered hydrogen bonding interactions, involving oxalamide $\mathrm{NH}$ or aromatic $\mathrm{CH}$ moieties, as hydrogen donors, in the stabilization of the observed conformation, is demonstrated. Thus the application of the three-centered hydrogen bonding interactions in switching from twisted oxalamide clefts to the planar ones is pointed out. This work is part of a more ambitious project directed to control the secondary structures of large synthetic molecules making use of the oxalamide motif, as building block, and the three centered hydrogen bond, as directing force. Further work is in progress, focused on the study of the association ${ }^{23}$ and assembling properties of these molecules. 


\section{Experimental Section}

Materials. 1,2-Phenylenediamine, 1,3-phenylenediamine, triethylamine (TEA), ethyl oxalyl chloride, oxalyl chloride, hydrazine, ethanolamine, 2-(2-aminoethylamino)ethanol, (S)-(+)-2amino-1-propanol, (1S,2R)-(+)-norephedrine, 3-aminophenol, 2-fluoroaniline, 2aminoacetophenone, 2-nitroaniline, $p$-toluenesulfonic acid monohydrate, THF and ethyl alcohol were purchased from Aldrich and used as received. Toluene was purchased from Merck and used as received. Diethyl $N, N^{\prime}$-(1,2-phenylene)dioxalamate $\mathbf{1 a}$ and diethyl $N, N^{\prime}-(1,3-$ phenylene)dioxalamate $\mathbf{1 b}$ were synthesized as reported for $\mathbf{1 b} .^{22}$ All new compounds were characterized by ${ }^{1} \mathrm{H}$ and ${ }^{13} \mathrm{C}$ NMR. The assignments were made on the basis of COSY and HETCOR experiments and for comparison to the reported values for similar compounds when possible. $^{14,16}$

General Procedures. Melting points were measured on an Electrothermal IA 9100 apparatus and are uncorrected. IR spectra were recorded in $\mathrm{KBr}$ discs using a Perkin-Elmer 16F PC IR spectrophotometer or neat on a Perkin-Elmer FT-IR Spectrum-GX equipped with an ATR device. ${ }^{1} \mathrm{H}$ and ${ }^{13} \mathrm{C}$ NMR spectra were recorded on a Varian Mercury $300\left({ }^{1} \mathrm{H}, 300.08 ;{ }^{13} \mathrm{C}, 75.46\right.$ $\mathrm{MHz}$ ) equipment in $\left[{ }^{2} \mathrm{H}_{6}\right] \mathrm{DMSO}$ solution, measured with $\mathrm{SiMe}_{4}$ as internal reference following standard techniques. Variable temperature experiments were performed on the same apparatus equipped with a temperature controller to keep the temperature constant within $0.2{ }^{\circ} \mathrm{C}$. The temperature was varied from $20-120^{\circ} \mathrm{C}$ in $10^{\circ}$ increments with a delay of 5 min for temperature stabilization. Each spectrum was obtained with 16 scans.

Diethyl $N, N^{\prime}$-(1,2-phenylene)dioxalamate (1a). It was synthesized using the procedure described for $\mathbf{1 b}$, starting from $5 \mathrm{~g}(46.2 \mathrm{mmol})$ of 1,2-phenylenediamine, to obtain $13.7 \mathrm{~g}$ $(96 \%)$ of a white solid. m.p. $=104-105{ }^{\circ} \mathrm{C}$; IR $(\mathrm{KBr}$ disc $) \cup_{\max }\left(\mathrm{cm}^{-1}\right)=3220(\mathrm{NH}) ; 1739,1758$, 1680, $1610(\mathrm{C}=\mathrm{O})$.

Diethyl $N, N^{\prime}$-(1,3-phenylene)dioxalamate (1b). To a THF (100 mL) solution of $5 \mathrm{~g}$ (46.2 mmol) of 1,3-phenylenediamine and $12.9 \mathrm{~mL}(9.4 \mathrm{~g}, 92.9 \mathrm{mmol})$ of TEA were added dropwise $10.0 \mathrm{~mL}$ (12.3 g, $98.3 \mathrm{mmol})$ of ethyl oxalyl chloride under nitrogen atmosphere with vigorous stirring at $0{ }^{\circ} \mathrm{C}$. The reaction mixture was additionally stirred for $4 \mathrm{~h}$ at room temperature. The suspension was filtered and the solid was washed with $\mathrm{H}_{2} \mathrm{O}$. THF solution was evaporated to dryness, washed with distilled water, mixed with the previously obtained solid and dried to yield $12.8 \mathrm{~g}(90 \%)$ of white solid. m.p. $=153-156{ }^{\circ} \mathrm{C}$; IR $(\mathrm{KBr}$ disc $) \mathrm{v}_{\max }\left(\mathrm{cm}^{-1}\right)=3349$ (NH); 1699.

$\boldsymbol{N}, \boldsymbol{N}^{\prime}$-1,2-Bis[(2-hydrazino)oxalyl]phenylenediamine (2a). To an ethyl alcohol (25 $\mathrm{mL}$ ) solution of $1 \mathrm{a}(5.0 \mathrm{~g}, 16.0 \mathrm{mmol})$ were added dropwise $1.02 \mathrm{~g}$ (32 mmol) of hydrazine under nitrogen atmosphere and vigorous stirring at $0{ }^{\circ} \mathrm{C}$. The reaction mixture was refluxed for $24 \mathrm{~h}$. The suspension was filtered off and the resulting solid was washed with cold ethyl alcohol 
(10 mL) and dried to yield $3.27 \mathrm{~g}$ (72 \%) of a white solid. m.p. = 203-204 ${ }^{\circ} \mathrm{C}$; IR ( $\mathrm{KBr}$ disc) $v_{\max }\left(\mathrm{cm}^{-1}\right)=3268(\mathrm{NH}) ; 1715,1680,1700(\mathrm{C}=\mathrm{O})$.

$\boldsymbol{N}, \boldsymbol{N}^{\prime}$-1,3-Bis[(2-hydrazino)oxalyl]phenylenediamine (2b). To a toluene (20 $\left.\mathrm{mL}\right)$ solution of $0.5 \mathrm{~g}$ (1.62 mol) of $\mathbf{1 b}$, were added $0.10 \mathrm{~mL}$ (3.2 mmol) of hydrazine. The reaction mixture was refluxed for $24 \mathrm{~h}$. The suspension was filtered off and the resulting solid was washed with cold toluene and dried to yield $0.41 \mathrm{~g}(90 \%)$ of a white solid. m.p. $=300{ }^{\circ} \mathrm{C} ; \operatorname{IR}(\mathrm{KBr}$ disc $) \cup_{\max }\left(\mathrm{cm}^{-1}\right)=3273(\mathrm{NH})$; $1731,1655(\mathrm{C}=\mathrm{O})$.

$N, N^{\prime}$-1,2-Bis[2-(2-hydroxy-ethylamino)oxalyl]phenylenediamine (3a). To an ethyl alcohol $(30 \mathrm{~mL})$ solution of $5 \mathrm{~g}(16.0 \mathrm{mmol})$ of 1a were added dropwise $1.92 \mathrm{~mL}$ (1.95 g, $32 \mathrm{mmol})$ of ethanolamine under vigorous stirring at room temperature. The reaction mixture was stirred additionally for $8 \mathrm{~h}$ at room temperature. The suspension was filtered and the resulting solid was washed with cold ethyl alcohol (3 mL) to yield $5.2 \mathrm{~g}(94 \%)$ of a white solid. m.p. $=226-227{ }^{\circ} \mathrm{C}$. IR $\left(\mathrm{KBr}\right.$ disc) $\cup_{\max }\left(\mathrm{cm}^{-1}\right)=3254(\mathrm{OH}), 3453,3450(\mathrm{NH}) ; 1655,1674(\mathrm{C}=\mathrm{O})$.

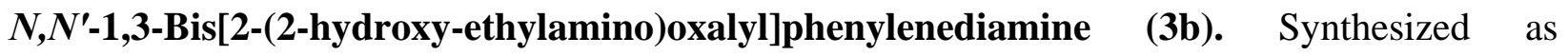
described for 3a, using $15 \mathrm{~mL}$ of ethyl alcohol as solvent, $1.0 \mathrm{~g}(3.2 \mathrm{mmol})$ of $\mathbf{1 b}, 0.38 \mathrm{~mL}$ $(0.39 \mathrm{~g}, 6.3 \mathrm{mmol})$ of ethanolamine and $0.1 \mathrm{~g}$ of $p$-toluenesulfonic acid as catalyst for $24 \mathrm{~h}$ of reflux. After filtering, the resulting solid was washed with ethyl acetate $(1 \mathrm{~mL})$ and acetone $(1 \mathrm{~mL})$ and dried to yield $0.98 \mathrm{~g}(90 \%)$ of a white solid. m.p. $=265{ }^{\circ} \mathrm{C}(\mathrm{d})$. IR (neat) $\mathrm{v}_{\max }\left(\mathrm{cm}^{-1}\right)$ = $3326(\mathrm{OH}), 3287(\mathrm{NH}), 1668(\mathrm{C}=\mathrm{O})$.

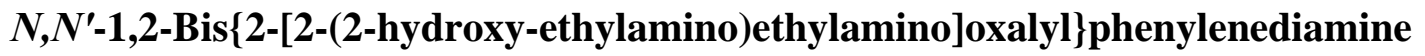

(4a). Synthesized as described for 2a using $20 \mathrm{~mL}$ of ethyl alcohol as solvent, $5.0 \mathrm{~g}$ (16.0 mmol) of 1a, $3.26 \mathrm{~mL}$ (3.3 g, $32 \mathrm{mmol})$ of 2-(2-aminoethylamino)ethanol. After drying were obtained $5.74 \mathrm{~g}(83 \%)$ of a white solid. m.p. $=164-165^{\circ} \mathrm{C}$; IR (KBr disc) $v_{\max }\left(\mathrm{cm}^{-1}\right)=3450(\mathrm{OH})$; 3321, $3253(\mathrm{NH}) ; 1674,1655$ (C=O).

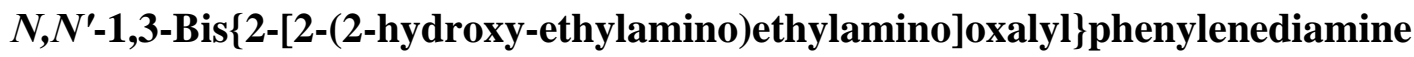

(4b). Synthesized as described for 3a, using $15 \mathrm{~mL}$ of ethyl alcohol as solvent, $1.0 \mathrm{~g}$ (3.2 mmol) of $\mathbf{1 b}$, a $0.64 \mathrm{~mL}(0.66 \mathrm{~g}, 6.4 \mathrm{mmol})$ of 2-(2-aminethylamino)ethanol and $0.1 \mathrm{~g}$ of $p$-toluenesulfonic acid as catalyst for $24 \mathrm{~h}$ of reflux. After filtering, the resulting solid was washed with ethyl acetate $(1 \mathrm{~mL})$ and acetone $(1 \mathrm{~mL})$ and dried to yield $0.99 \mathrm{~g}(72 \%)$ of a white solid m.p. $=$ $217^{\circ} \mathrm{C}$. IR (neat) $v_{\max }\left(\mathrm{cm}^{-1}\right)=3314,3277(\mathrm{NH}), 3055(\mathrm{OH}), 1660.7(\mathrm{C}=\mathrm{O})$.

$N, N^{\prime}-1,3-B i s[2-(2-h y d r o x y-1(S)$-methyl-ethylamino)oxalyl]phenylenediamine

(5b).

Synthesized as described for $\mathbf{2 b}$, using $20 \mathrm{~mL}$ of toluene as solvent, $0.25 \mathrm{~g}$ (0.81 mmol) of $\mathbf{1 b}$, $0.15 \mathrm{~mL}$ (0.14 g, $1.93 \mathrm{mmol})$ of $(S)-(+)$-2-amino-1-propanol. The reaction mixture was refluxed for $48 \mathrm{~h}$. The suspension was filtered off and the resulting solid was washed with toluene (2 mL) and dried in vacuo to yield $0.243 \mathrm{~g}(82 \%)$ of a white solid. m.p. $=273{ }^{\circ} \mathrm{C}$; $\mathrm{IR}(\mathrm{KBr}$ disc) $\mathrm{v}_{\max }\left(\mathrm{cm}^{-1}\right)=3287(\mathrm{NH}), 1656(\mathrm{C}=\mathrm{O})$.

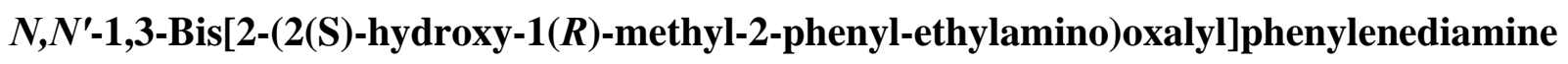
(6b). Synthesized as described for $5 \mathbf{b}$, starting from $0.5 \mathrm{~g}(1.62 \mathrm{mmol})$ of $\mathbf{1 b}$ and $0.66 \mathrm{~g}$ (4.36 mmol) of $(1 S, 2 R)-(+)$-norephedrine to yield $0.757 \mathrm{~g}(90.1 \%)$ of a white solid. m.p. $=252-$ $253{ }^{\circ} \mathrm{C}$; IR (KBr disc) $U_{\max }\left(\mathrm{cm}^{-1}\right)=3566(\mathrm{OH}), 3319(\mathrm{NH}), 1657(\mathrm{C}=\mathrm{O})$. 
$\boldsymbol{N}, \boldsymbol{N}^{\prime}$-1,3-Bis[2-(3-hydroxy-phenylamino)oxalyl]phenylenediamine (7b). Synthesized as described for $\mathbf{8 b}$, starting from $0.25 \mathrm{~g}$ ( $2.3 \mathrm{mmol}$ ) of 1,3-phenylenediamine, $0.64 \mathrm{~mL}$ (4.6 mmol) of TEA and $0.40 \mathrm{~mL}(0.586 \mathrm{~g}, 4.6 \mathrm{mmol})$ of oxalyl chloride. The last addition was of $0.504 \mathrm{~g}$ (4.6 mmol) of 3-aminophenol, $0.64 \mathrm{~mL}$ of TEA (4.6 mmol) to obtain $0.50 \mathrm{~g}(49.7 \%)$ of a white solid m.p. $=245^{\circ} \mathrm{C}$. IR $(\mathrm{KBr}$ disc $) v_{\max }\left(\mathrm{cm}^{-1}\right)=3288(\mathrm{NH}) ; 1665(\mathrm{C}=\mathrm{O})$.

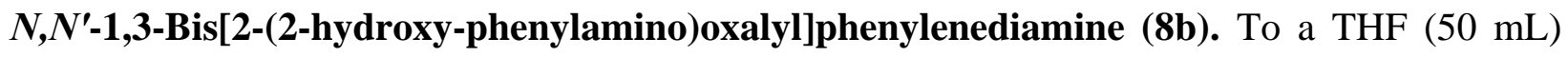
solution of $0.25 \mathrm{~g}$ ( $2.3 \mathrm{mmol})$ of 1,3-phenylenediamine and $0.64 \mathrm{~mL}$ of TEA (4.6 mmol) were added dropwise $0.40 \mathrm{~mL}(0.586 \mathrm{~g}, 4.6 \mathrm{mmol})$ of oxalyl chloride solved in $50 \mathrm{~mL}$ of THF under nitrogen atmosphere and vigorous stirring at $4{ }^{\circ} \mathrm{C}$. The reaction mixture was additionally stirred for $1 \mathrm{~h}$ at room temperature, after that $0.504 \mathrm{~g}(4.61 \mathrm{mmol})$ of 2-aminophenol and $0.64 \mathrm{~mL}$ of TEA (4.6 mmol) solved in $50 \mathrm{~mL}$ of THF solution were added dropwise under nitrogen atmosphere and vigorous stirring at $0-5{ }^{\circ} \mathrm{C}$. The reaction mixture was stirred additionally for $1 \mathrm{~h}$ to room temperature. The suspension was filtered and washed with cold THF (3 mL), to obtain 0.5 g (49.7 \%) of a white solid m.p. $=294{ }^{\circ} \mathrm{C}$. IR $(\mathrm{KBr}$ disc $) \mathrm{U}_{\max }\left(\mathrm{cm}^{-1}\right)=3291(\mathrm{NH}) ; 1665$ $(\mathrm{C}=\mathrm{O})$.

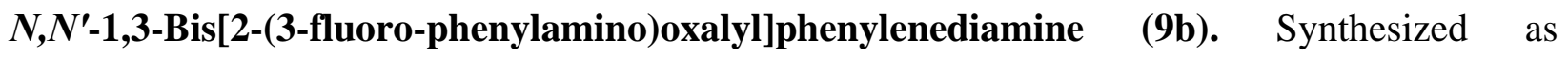
described for $\mathbf{8 b}$, starting from $0.5 \mathrm{~g}$ (4.6 mmol) of 1,3-phenylenediamine, $1.28 \mathrm{~mL}$ (9.2 mmol) of TEA and $0.80 \mathrm{~mL}(1.17 \mathrm{~g}, 9.2 \mathrm{mmol})$ of oxalyl chloride. The last addition was of $1.11 \mathrm{~mL}$ (11.5 mmol) of 2-fluoroaniline and $1.28 \mathrm{~mL}(9.2 \mathrm{mmol})$ of TEA to obtain $1.02 \mathrm{~g}(50.3 \%)$ of a white solid m.p. $=298{ }^{\circ} \mathrm{C}$. IR $(\mathrm{KBr}$ disc $) v_{\max }\left(\mathrm{cm}^{-1}\right)=3295(\mathrm{NH}) ; 1672(\mathrm{C}=\mathrm{O})$.

$\boldsymbol{N}, \boldsymbol{N}^{\prime}$-1,3-Bis[2-(2-acetyl-phenylamino)oxalyl]phenylenediamine (10b). Synthesized as described for $\mathbf{8 b}$, starting from $0.5 \mathrm{~g}$ (4.6 mmol) of 1,3-phenylenediamine, $1.28 \mathrm{~mL}$ (9.2 mmol) of TEA and $0.80 \mathrm{~mL}(1.173 \mathrm{~g}, 9.2 \mathrm{mmol})$ of oxalyl chloride. The last addition was of $1.12 \mathrm{~mL}$ (9.2 mmol) of 2-aminoacetophenone and $1.28 \mathrm{~mL}$ (9.2 mmol) of TEA to obtain $1.5 \mathrm{~g}(66.7 \%)$ of a white solid m.p. $=294{ }^{\circ} \mathrm{C}$. IR $\left(\mathrm{KBr}\right.$ disc) $\mathrm{v}_{\max }\left(\mathrm{cm}^{-1}\right)=3346,3293(\mathrm{NH}) ; 1674 \mathrm{~b}(\mathrm{C}=\mathrm{O})$.

$\boldsymbol{N}, \boldsymbol{N}^{\prime}$-1,3-Bis[2-(2-nitro-phenylamino)oxalyl]phenylenediamine (11b). Synthesized as described for $\mathbf{8 b}$, starting from $0.5 \mathrm{~g}$ (4.6 mmol) of 1,3-phenylenediamine, $1.28 \mathrm{~mL}(9.2 \mathrm{mmol})$ of TEA and $0.80 \mathrm{~mL}(1.173 \mathrm{~g}, 9.2 \mathrm{mmol})$ of oxalyl chloride. The last addition was of $1.277 \mathrm{~g}$ (9.2 mmol) of 2-nitroaniline and $1.28 \mathrm{~mL}(9.2 \mathrm{mmol})$ of TEA to obtain $1.3 \mathrm{~g}$ (57 \%) of a yellow solid m.p. $=266{ }^{\circ} \mathrm{C}(\mathrm{d}) . \mathrm{IR}(\mathrm{KBr}$ disc $) v_{\max }\left(\mathrm{cm}^{-1}\right)=3294(\mathrm{NH}) ; 1671,1607(\mathrm{C}=\mathrm{O})$.

Theoretical calculations. The structure of compounds $1 \mathbf{a}$ and $\mathbf{1 b}$ were optimized using the HF $6-31++\mathrm{G}$ basis set. The optimized geometries were found in close approach to the experimental crystal data. Thereafter, single point calculations at the HF 6-31++G basis set were performed on the optimized structures to obtain the potential-derived charges using the Merz-Kollman-Singh scheme. All calculations were done using the Gaussian98 program. ${ }^{24}$ 


\section{Acknowledgements}

The authors acknowledge the financial support of CGPI-IPN (Coordinación General de Posgrado e Investigación del Instituto Politécnico Nacional) Mexico.

\section{References}

1. Babine, R. E.; Bener, S. L. Chem. Rev. 1997, 97, 1359.

2. Chou, H.-C.; Hsu, C.-H.; Cheng, Y.-M.; Cheng, C.-C.; Liu, H.-W.; Pu, S.-C.; Chou, P.-T. J. Am. Chem. Soc. 2004, 126, 1650.

3. Faraoni, R.; Castellano, R. K.; Gramlich, V.; Diederich, F. Chem. Comun. 2004, 370.

4. Condo, M.; Okamoto, K.; Nishi, I.; Yamamoto, M.; Jelokhsni-Niekari, M.; Kodama H. Bull. Chem. Soc. Jpn. 67 1994, 1064.

5. Abbas, A. A. Synthesis 2004, 3, 419.

6. Chang, S.-Y.; Kim, H.-S.; Chang, K.-J.; Jeong, K.-S. Org. Lett. 2004, 6, 181.

7. Benito, J. M.; Gómez-García M.; Jiménez-Blanco, J. L; Ortiz-Mellet, C.; García-Fernández, J. M. J. Org. Chem. 2001, 66, 1366.

8. Albrecht, M.; Zauner, J.; Frohlich, R.; Kataeva, O.; Wegelius, E. Y.; Rissanen, K. Synthesis 2002, 10, 1434.

9. Nguyen, T. L.; Fowler, F. W.; Lauher, J. W. J. Am. Chem. Soc. 2001, 123, 11057.

10. García-Báez, E. V.; Gómez-Castro, C. Z.; Höpfl, H.; Martínez-Martínez, F. J.; PadillaMartínez, I. I. Acta Cryst. 2003, C59, 541.

11. Luo, X.; Li, C.; Liang, Y. Chem. Comm. 2000, 2091.

12. Toda, F.; Tagami, Y.; Mak, T. C. W. Bull. Chem. Soc. Jpn. 1986, 59, 1189.

13. Alemán, C.; Casanovas, J. J. Mol. Struct. 2004, 675, 9.

14. Martínez-Martínez, F. J.; Padilla-Martínez, I. I.; Brito, M. A.; Geniz, E. D.; Rojas, R. C.; Saavedra, J. B. R.; Höpfl, H.; Tlahuextl, M.; Contreras, R. J. Chem. Soc. Perkin Trans 2, 1998, 401.

15. Zhu, J.; Wang, X.-Z.; Chen, Y.-Q.; Jiang, X.-K.; Chen, X.-Z.; Li, Z.-T. J. Org. Chem. 2004, 69, 6221 and references cited therein.

16. Padilla-Martínez, I. I.; Martínez-Martínez, F. J.; García-Baez, E. V.; Torres-Valencia, J. M.; Rojas-Lima, S.; Höpfl, H. J. Chem. Soc. Perkin Trans 2 2001, 1817.

17. Nuñez, L.; Barral, L.; Pilcher, G. J. Chem. Thermodynamics 1988. 20, 1211.

18. Kessler, H. Angew. Chem. Int. Ed. Engl. 1982, 21, 512.

19. Dewar, M. J. S.; Schmeizing, H. N. Tetrahedron 1968, 11.

20. Martínez-Martínez, F. J.; Rojas-Pérez, E. E.; García-Báez, E. V.; Höpfl, H.; PadillaMartínez I. I. Acta Crystallogr. 2004, C60, o699.

21. Martin, S.; Beitia, J. I.; Ugalde, M.; Vitoria, P.; Cortes, R. Acta Crystallogr. 2002, E59, 913. 
22. Padilla-Martínez, I. I.; Chaparro-Huerta, M.; Martínez-Martínez, F. J.; Höpfl, H.; GarcíaBáez, E. V. Acta Crystallogr. 2004, E59, 0825.

23. Gómez, M; Gómez-Castro, C. Z.; Padilla-Martínez, I. I.; Martínez-Martínez, F. J.; González, F. J. J. Electroanal. Chem. 2004, 567, 269.

24. Frisch, M. J.; Trucks, G. W.; Schlegel, H. B.; Scuseria, G. E.; Robb, M. A.; Cheeseman, J. R.; Zakrzewski, V. G.; Montgomery, Jr. J. A.; Stratmann, R. E.; Burant, J. C.; Dapprich, S.; Millam, J. M.; Daniels, A. D.; Kudin, K. N.; Strain, M. C.; Farkas, O.; Tomasi, J.; Barone, V.; Cossi, M.; Cammi, R.; Mennucci, B.; Pomelli, C.; Adamo, C.; Clifford, S.; Ochterski, J.; Petersson, G. A.; Ayala, P. Y.; Cui, Q.; Morokuma, K.; Malick, D. K.; Rabuck, A. D.; Raghavachari, K.; Foresman, J. B.; Cioslowski, J.; Ortiz, J. V.; Baboul, A. G.; Stefanov, B. B.; Liu, G.; Liashenko, A.; Piskorz, P.; Komaromi, I.; Gomperts, R.; Martin, R. L.; Fox, D. J.; Keith, T.; Al-Laham, M. A.; Peng, C. Y.; Nanayakkara, A.; Gonzalez, C.; Challacombe, M.; Gill, P. M. W.; Johnson, B.; Chen, W;. Wong, M. W.; Andres, J. L.; Gonzalez, C.; Head-Gordon, M.; Replogle, E. S.; J. A. Pople, Gaussian98 (Revision A.7), Pittsburgh PA, 1998. 